\title{
Valorization of various sources of rabbit manure in agro- piscicultural system in Benin (West Africa): dynamics and effect of mineralization upon quality of fresh water
}

\author{
Richard Adande $^{1} \cdot$ Hervé Kouessivi Janvier Bokossa ${ }^{1} \cdot$ Mouhamadou Nourou Dine Liady $^{1}$. \\ Emile Didier Fiogbé ${ }^{1}$
}

Received: 28 December 2016/Accepted: 20 July 2017/Published online: 29 July 2017

(C) The Author(s) 2017. This article is an open access publication

\begin{abstract}
Purpose Rising demand of fish generates various pressures on aquatic ecosystems, causing its deterioration and the loss of its biodiversity. With the aim of a better management and fish production in a salubrious environment, this study proposes the utilization of organic fertilizers from rabbit manure.

Methods The treatments consisted of manure of rabbits fed with: manufactured diet $\left(\mathrm{T}_{1}\right)$, improved diet with Ipomea aquatic $\left(\mathrm{T}_{2}\right)$, improved diet with Elaeis guineensis $\left(\mathrm{T}_{3}\right)$, and improved diet with Panicum maximum $\left(\mathrm{T}_{4}\right)$. Indeed, experimental design was a completely randomized block design with three replications. $6 \mathrm{~g}$ in $10 \mathrm{~L}$ of water from the different manures from each diet was followed during 50 days. Various nutrients were measured.

Results After the mineralization process, the best manure which released more nutrients was $\mathrm{T}_{4}$ with measured proportions of ${\mathrm{N}-\mathrm{NO}_{2}}^{-}, \mathrm{N}_{-} \mathrm{NO}_{3}{ }^{-}, \mathrm{N}_{-} \mathrm{NH}_{3}, \mathrm{P}_{-} \mathrm{PO}_{4}{ }^{3-}, \mathrm{Ca}^{2+}$, $\mathrm{Mg}^{2+}, \mathrm{K}^{+}$, and suspended matter being $0.06 \pm 0.0$, $0.38 \pm 0.1,0.85 \pm 0.1,8.27 \pm 0.9,12.11 \pm 0.8,4.47 \pm$ $0.3,3.02 \pm 0.2$, and $140.78 \pm 18.6 \mathrm{mg} / \mathrm{L}$, respectively. The highest content of phosphorus and nitrogen was recorded in $\mathrm{T}_{4}$ and $\mathrm{T}_{2}$, respectively. The principal component analysis showed a positive correlation between $\mathrm{P}^{-} \mathrm{PO}_{4}{ }^{3-}, \mathrm{Ca}^{2+}, \mathrm{Mg}^{2+}$, MES, conductivity, and salinity during mineralization.
\end{abstract}

Richard Adande

richard_adande@yahoo.fr

1 Laboratory of Research in the Wetlands (LRZH), Faculty of Science and Techniques (FAST), University of AbomeyCalavi (UAC), 01 BP 526, Cotonou, Benin
Conclusion Manure from rabbits fed by an improved diet with $P$. maximum $\left(\mathrm{T}_{4}\right)$ was recommended for agro-piscicultural production system.

Keywords Rabbit manure - Mineralization · Water . Nutrient · Agro-piscicultural

\section{Introduction}

Today, aquaculture is increasingly developing in the world (e.g., over $60 \%$ of the total fish production in China) despite the serious environmental problems that may occur ( $\mathrm{Li} 2002$; Lazard 2014). Although it remains under developed in most parts of Africa (Lazard 2014), its production has increased in recent years, compared to other livestock such as pigs, cows, and poultry (FAO 2010). Similarly, the strong fish demand has increased with population growth (FAO 2012). However, such demand has led to the deterioration of natural resources, especially quality, with the loss of its biodiversity (Moura E Silva et al. 2016). Fish farming could play a key role in facing the challenge of rising demands of animal proteins (Kaushik 2014). Strengthening the sector depends upon the efficient use of organic fertilizers of animal origin for an optimal primary production in fish conventional systems (Goulding et al. 2008). Indeed, the burst of optimal and sustainable fish farming must necessarily use a dynamic resource available such as organic fertilizers (FAO 2012). Thus, organic fertilizer use is a suitable alternative for agricultural activities to improve fish productivity and yields (Pucher et al. 2012; Bokossa et al. 2014a). Steinbronn (2009) showed that aquaculture production contributes significantly to food security, generates income, and plays a significant role in farmers' livelihood strategies. According to Wilkins (2008), the practice of integrated systems (animal and plant 
production) would give an economic and ecological efficiency in operations. Likewise, Wilkins (2008) and Lemaire et al. (2013) revealed that this practice would reduce the loss of nitrogen, phosphorus, and carbon to the environment and might limit the use of chemical fertilizers. Although animal manures have been investigated in zooplankton production in West African countries (e.g., Akodogbo et al. 2015), to our best knowledge, no study has dealt with the nutrients released in water from manure of rabbits.

The aims of our study were to (i) determine the effect of the diet on manure quality and (ii) assess the water quality and nutrient dynamics during the mineralization process.

\section{Materials and methods}

\section{Experimental site}

The experiment was conducted from June to August 2016 at a site $\left(6^{\circ} 24^{\prime} 53.3^{\prime \prime} \mathrm{N} ; 2^{\circ} 20^{\prime} 18.5^{\prime \prime} \mathrm{E}\right.$; altitude $9 \mathrm{~m}$ above sea level) located at the University of Abomey-Calavi Benin. The area is characterized by a sub-equatorial climate with two rainy seasons (March to end of July and mid-September to November) and two dry seasons (August to mid-September and December to March).

\section{Rabbits (Oryctolagus cuniculus) feeding and manure collection}

The rabbit manure was obtained from 36 8-month-old local breed young rabbits. Four triplicates including a control were formulated. They were placed in 12 galvanized iron cages of $1 \mathrm{~m}$ length, $0.5 \mathrm{~m}$ wide, and $0.5 \mathrm{~m}$ height each. The cages were randomly placed in a hangar. Each cage was equipped by a manger and a trough. Nets of mesh $(0.1 \mathrm{~mm})$ were suspended to the bottom of the cages to collect rabbit manures. Rabbit manures were stored in bags of $25 \mathrm{~kg}$.

Four diets were involved during the study period: classic manufactured $\left(\mathrm{T}_{1}\right)$, improved diet with Ipomea aquatic $\left(\mathrm{T}_{2}\right)$, improved diet with Elaeis guineensis $\left(\mathrm{T}_{3}\right)$, and improved diet with Panicum maximum $\left(\mathrm{T}_{4}\right)$. $\mathrm{T}_{1}$ was manufactured locally by a veterinarian society service. Its chemical composition comprised: proteins (raw material) $17 \%$, calcium $\geq 1.14 \%$, total phosphorus $\geq 0.8 \%$, lysine $\geq 0.75 \%$, methionine + cystine $\geq 0.6 \%$, crude fat $\geq 2 \%$, crude fiber $\geq 14 \%$, and $\geq 0.1 \%$ flavomycine.

The compositions of the three other diets were:

$\mathrm{T}_{2}$ Tuber cassava $2 \%$, born bran $20 \%$, palm kernel meal $10 \%$, soy bran $10 \%$, cottonseed meal $15 \%$, shell $2 \%$, distillers grains $20 \%$, Azolla filiculoïdes $10 \%$, brewer's yeast $5 \%$, Ipomoea aquatica $15 \%$, and salt $1 \%$.
$\mathrm{T}_{3}$ Cossette cassava $2 \%$, corn bran $25 \%$, palm kernel meal $15 \%$, soy bran $5 \%$ cottonseed meal $10 \%$, shell $2 \%$, distillers grains 15\%, Azolla filiculö̈des 5\%, brewer's yeast $10 \%$, Elaeis guineensis $10 \%$, and salt $1 \%$.

$\mathrm{T}_{4}$ Cossette cassava $2 \%$, corn bran $30 \%$, palm kernel meal $10 \%$, soy bran $10 \%$, cottonseed meal $5 \%$, shell $2 \%$, distillers grains $10 \%$, Azolla filiculö̈des $5 \%$, brewer's yeast $15 \%$, Panicum maximum $10 \%$, and salt $1 \%$.

\section{Experimental design and water enrichment process}

The experimental design was a completely randomized block design with three replications. The treatments consisted of the different types of manure collected from the experimental cages. The rabbit manures were grounded into nylon mosquito toils with a mesh size of $1 \mathrm{~mm}$. For each treatment, 12 nylon mesh bags containing $6 \mathrm{~g}$ of dried manures were tied and suspended in $10 \mathrm{~L}$ of water (Mascha et al. 2010; Agadjihouèdé et al. 2011; Qiu et al. 2012; Bokossa et al. 2014a). A total of 150 plastic buckets (10 lots $\times 15$ buckets) were used in the experiment. Each manure nylon mesh bags were placed randomly within 12 buckets. Three control (no fertilizer) buckets per lot were used. They were used for calibration purpose (i.e., correct the values form fertilized buckets). Half of the ten lots were sampled every 3 days, while the remaining was sampled every 7 days to take into account the labile and resistant fractions, respectively. At the sampling date, 12 nylon bags containing manures were collected, as well as 15 water samples of $500 \mathrm{ml}$ each (including three controls). Water samples were then sent to the laboratory for analysis.

In all the buckets, temperature, $\mathrm{pH}$, conductivity, dissolved oxygen, total dissolved solids (TDS), and salinity were measured "in situ" at the sampling days with a multiparameter probe (softer version/2015 2138 SN-ODEON CALYPSO; $\pm 0.1{ }^{\circ} \mathrm{C}$ sensitivity).

\section{Mineralization process and water analysis}

Water samples were stored in a refrigerator at $4{ }^{\circ} \mathrm{C}$ to evaluate the released nutrients during the mineralization process. Analyses included the determination of suspended solids, $\mathrm{N}-\mathrm{NO}_{3}{ }^{-}, \mathrm{N}_{-} \mathrm{NO}_{2}{ }^{-}, \mathrm{N}-\mathrm{NH}_{3}, \mathrm{P}-\mathrm{PO}_{4}{ }^{3-}, \mathrm{Mg}^{2+}, \mathrm{K}^{+}$, and $\mathrm{Ca}^{2+}$ contents. Their measurement was performed using a molecular absorption spectrophotometer (DR 2800). After homogenization of the mixture, the suspended solids were measured at a wavelength of $810 \mathrm{~nm}$. The ammonia combines with chlorine to form monochloramine which reacts with salicylate to form 5-aminosalicylate. $\mathrm{N}-\mathrm{NH}_{3}$ content was obtained at $655 \mathrm{~nm}$. Regarding 
Table 1 Chemical

characteristics of rabbit manure regarding the composition of the diet used to feed the animal

\begin{tabular}{lllll}
\hline Treatment & \multicolumn{4}{l}{ Nutrient content $(\mathrm{mg} / \mathrm{L})$} \\
\cline { 2 - 5 } & $\mathrm{N}$ & $\mathrm{P}$ & $\mathrm{K}$ & $\mathrm{N}: \mathrm{P}$ \\
\hline $\mathrm{T}_{1}$ & $12.33 \pm 0.01 \mathrm{c}$ & $1.03 \pm 0.00 \mathrm{c}$ & $1.66 \pm 0.05 \mathrm{~b}$ & $11.97 \pm 0.07 \mathrm{bc}$ \\
$\mathrm{T}_{2}$ & $16.34 \pm 0.03 \mathrm{a}$ & $1.04 \pm 0.00 \mathrm{bc}$ & $2.19 \pm 0.23 \mathrm{a}$ & $15.66 \pm 0.15 \mathrm{a}$ \\
$\mathrm{T}_{3}$ & $14.02 \pm 0.58 \mathrm{~b}$ & $1.06 \pm 0.01 \mathrm{~b}$ & $0.79 \pm 0.04 \mathrm{c}$ & $13.23 \pm 0.64 \mathrm{~b}$ \\
$\mathrm{~T}_{4}$ & $15.02 \pm 0.58 \mathrm{ab}$ & $1.26 \pm 0.00 \mathrm{a}$ & $0.84 \pm 0.02 \mathrm{c}$ & $11.89 \pm 0.44 \mathrm{c}$ \\
$\mathrm{CV}(\%)$ & 14.43 & 1.09 & 1.37 & 13.19 \\
\hline
\end{tabular}

$C V$ coefficient of variation

Means followed by the same letter are not significantly different $(p>0.05)$ according to the LSD. Treatments' description: $T_{1}$ manufactured diet, $T_{2}$ improved diet with Ipomea aquatica; $T_{3}$ improved diet with Elaeis guineensis, and $T_{4}$ improved diet with Panicum maximum
$\mathrm{N}-\mathrm{NO}_{3}{ }^{-}$, the cadmium reduces nitrate to nitrite sample. The nitrite ion reacts with sulfanilic acid to form an intermediate diazonium salt. The nitrite present in the sample reacts with sulfanilic acid to form an intermediate diazonium salt. This combines with chlorotropique acid to produce a pink-colored complex, whose intensity is directly proportional to the nitrite concentration in the solution. The reading was obtained at $507 \mathrm{~nm}$. $\mathrm{P}_{-} \mathrm{PO}_{4}{ }^{3-}$ was measured by the colorimetric method using blue ammonium molybdate reagent; measurements were realized at a wavelength of $880 \mathrm{~nm} . \mathrm{K}^{+}, \mathrm{Ca}^{2+}$, and $\mathrm{Mg}^{2+}$ concentrations were determined by atomic absorption spectrophotometry (Rodier et al. 2012).

\section{Data Analysis}

The SAS software (SAS Version 9.2, SAS Institute Inc., Cary, NC, USA) was used for data analysis. The ANOVA was performed on the nutrient released in water during the decomposition process using time and treatments as factors. Main effects and interactions between treatments were assessed for significance levels, and separation was conducted using Fisher's protected LSD test. All levels of significance were set at $p$ value $<0.05$. A principal component analysis (PCA) was also performed to assess the correlation between different parameters. This was done using the STATISTICA software (Statsoft inc., Tulsa, OK, USA).

\section{Results}

\section{Influence of the diet on manure quality}

The nutrient content from the manure from rabbits fed with the different diets are presented in Table 1. The potassium, phosphorus, and nitrogen contents were significantly different $(p<0.05)$ between treatments. $\mathrm{N}: \mathrm{P}: \mathrm{K}$ ratios from $\mathrm{T}_{4}, \mathrm{~T}_{3}, \mathrm{~T}_{2}$, and $\mathrm{T}_{1}$ were, respectively, 18:2:1, 18:1:1, 8:1:1, and 7:1:1. For nitrogen content, treatments can be classified as $\mathrm{T}_{2}>\mathrm{T}_{4}>\mathrm{T}_{3}>\mathrm{T}_{1}$, while for the phosphorus content, the classification was $\mathrm{T}_{4}>\mathrm{T}_{3}>\mathrm{T}_{2}>\mathrm{T}_{1}$. Regarding $\mathrm{N}: \mathrm{P}$ ratios, the order was $\mathrm{T}_{2}>\mathrm{T}_{3}>\mathrm{T}_{1}>\mathrm{T}_{4}$ (Table 1). Overall, the manures from rabbits fed with improved diet with Panicum maximum had significantly high phosphorus content $(p<0.05)$. Whereas manures from rabbits fed with improved diet with Ipomea aquatica recorded the highest nitrogen content.

\section{Water quality and nutriment dynamics}

The ANOVA (Table 2) showed that the diet had significant influence on nutrient contents including $\mathrm{N}-\mathrm{NO}_{2}{ }^{-}, \mathrm{N}_{-}-\mathrm{NO}_{3}{ }^{-}$, $\mathrm{N}-\mathrm{NH}_{3}, \quad \mathrm{P}_{-} \mathrm{PO}_{4}{ }^{3-}, \mathrm{Mg}^{2+}, \mathrm{K}^{+}$, and suspended solid $(p<0.0001)$, and $\mathrm{Ca}^{2+}(p<0.05)$. However, no significant effect was noticed for the in situ parameters $(p>0.05)$ (Table 2). The time significantly influenced all the measured parameters $(p<0.05)$, thus showing that nutrient and "in situ" parameters changed with time. The different nutrient dynamics depended on the diet: the treatment-time interaction was significant for all nutrients $(p<0.0001)$, except $\mathrm{P}_{-} \mathrm{PO}_{4}{ }^{3-}$, whereas it was not for the "in situ" parameters.

The physicochemical quality of water was affected by the release of the various fertilizing elements from rabbit manures (Table 3). The increase of conductivity, temperature, $\mathrm{pH}$, dissolved oxygen, dissolved total solids, and salinity was found for all the treatments during the process of the enrichment of water following the decomposition of rabbit manures during 50 days of the experimentation in a progressive way. However, no significant difference between the treatments was found at the end of the experiment (Fig. 1; Table 3). Indeed, the temperature ranged from $29.66 \pm 0.3$ to $29.81 \pm 0.3$ in all the treatments. The conductivity was $240.85 \pm 14.5,239.72 \pm$ $14.0,238.98 \pm 13.5$, and $237.58 \pm 14.1 \mu \mathrm{S} / \mathrm{cm}$ in treatments $T_{4}, T_{2}, T_{3}$, and $T_{1}$, respectively. A high increase of conductivity was recorded in the treatments resulting from 


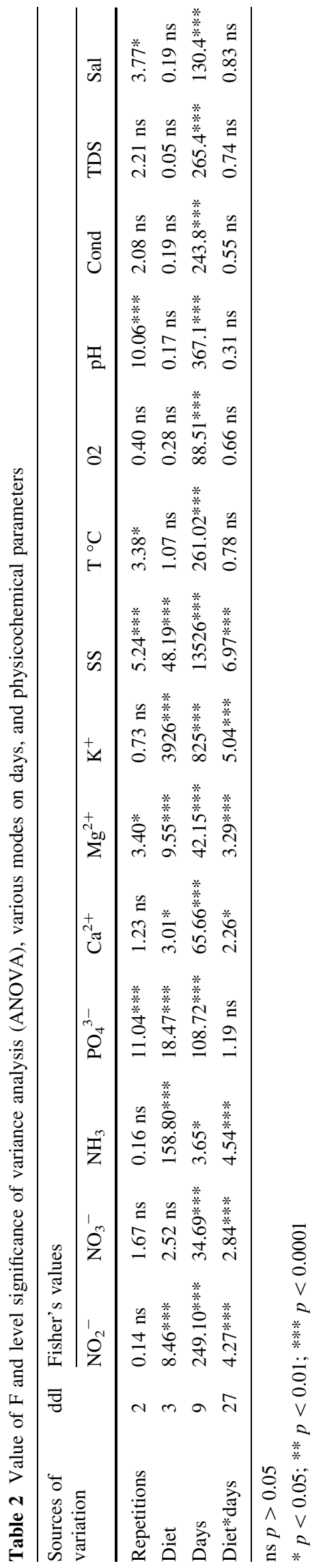

tested diets $\left(\mathrm{T}_{4}, \mathrm{~T}_{3}\right.$, and $\left.\mathrm{T}_{2}\right)$ compared to those from the standard diet $\left(\mathrm{T}_{1}\right)$. That could be explained by a higher release of ortophosphate, salinity, suspended solids, calcium, and magnesium in the improved diets (Table 3). There was no significant difference between treatments for $\mathrm{pH}$, dissolved oxygen, TDS, and salinity. This result can be explained by similar experimental condition and microorganism activity in the buckets.

The different types of manure have induced significant increase in $\mathrm{N}$ fractions $\left(\mathrm{N}-\mathrm{NH}_{3}, \mathrm{~N}^{-\mathrm{NO}_{3}}{ }^{-}\right.$, and $\mathrm{N}-\mathrm{NO}_{2}{ }^{-}$) at the end of experiment. The $\mathrm{K}^{+}, \mathrm{Ca}^{2+}, \mathrm{Mg}^{2+}, \mathrm{P}_{-} \mathrm{PO}_{4}{ }^{3-}$, and suspended solid contents in the water at the end of the decomposition process of the rabbit manures fed with different diets had also significantly increased $(p<0.05)$ as indicated by the large amount of released nutrients.

According to the observed nutrient dynamics (Table 3), nitrites increased during the first week before decreasing in the last weeks of the experimentation in all the treatments generally. Such a dynamic was noticeable particularly in $\mathrm{T}_{1}$, $\mathrm{T}_{2}$, and $\mathrm{T}_{3}$. Mean $\mathrm{NO}_{2}{ }^{-}$values in the different treatments increased from $0.0 \pm 0.0 \mathrm{mg} / \mathrm{L}\left(\mathrm{T}_{1}\right)$ to $0.1 \pm 0.0 \mathrm{mg} / \mathrm{L}\left(\mathrm{T}_{4}\right)$ during 50 days. These variations can be explained by the microbial activity which influences the permanent availability of nitrites. The reductions of nitrates in the treatments were revealed from the 9th days. These reductions were related to the ambient temperature. Indeed, when temperature became high, biochemical reactions were very important affecting nitrogen transformation or bacteria denitrification. The highest $\mathrm{N}^{-\mathrm{NO}_{3}}{ }^{-}$concentrations were obtained in $\mathrm{T}_{2} \quad(0.38 \pm 0.1 \mathrm{mg} / \mathrm{L})$ followed by $\mathrm{T}_{4}$ $(0.33 \pm 0.0 \mathrm{mg} / \mathrm{L})$. During the experiment, the average $\mathrm{N}-\mathrm{NH}_{3}$ content ranged from $0.43 \pm 0.0 \mathrm{mg} / \mathrm{L}$ in $\mathrm{T}_{1}$ to $1.62 \pm 0.0 \mathrm{mg} / \mathrm{L}$ in $\mathrm{T}_{4}$. However, significant decreases by $3.67,1.9$, and 1.26 times were noticed in ammonium concentrations in the manure from treatments $T_{1}, T_{2}$, and $T_{3}$, respectively, compared to $T_{4}$. This is related to the equilibrium constant which can be favourable to a massive loss of nitrogen as ammonia gas or favourable to storage in water as $\mathrm{NH}_{4}{ }^{+}$. In the rabbit manures, the volatilization process of ammonia consisted in the transfer of ammonia gas in the immediate atmosphere from ammonia in manure decomposing in water during experimentation. The concentration of orthophosphate, which was $10.83 \pm 1.0 \mathrm{mg} / \mathrm{L}$ in the $\mathrm{T}_{4}$ treatment, was $1.33,1.30$, and 1.2 times higher, respectively, than in treatments $\mathrm{T}_{1}, \mathrm{~T}_{2}$, and $\mathrm{T}_{3}(p<0.05)$. Tendency similar trend was practically noticed with the other elements such as $\mathrm{Ca}^{2+}, \mathrm{Mg}^{2+}$, and $\mathrm{K}^{+}$. This result revealed the richness of $\mathrm{T}_{4}$ compared to the others treatments. We also noticed a rapid increase of $\mathrm{K}^{+}$concentrations in $\mathrm{T}_{2}$ contrary to $T_{1}$; while $T_{3}$ and $T_{4}$ indicated during the first 12 days of experiment a rapidly mineralizable labile fraction of organic matter even from this time to the end of the experiment, a readily degradable fraction was found in rabbit manure. 


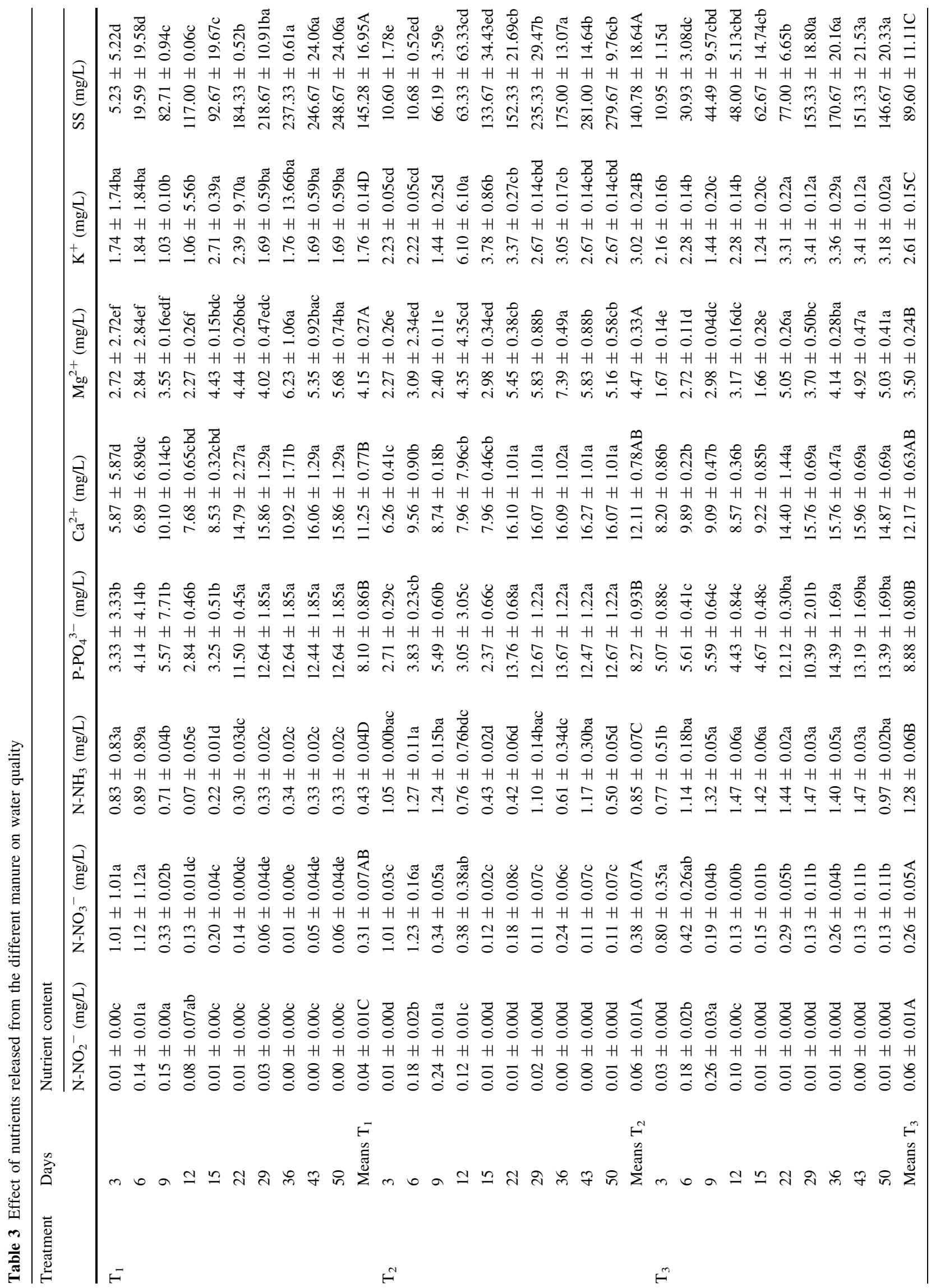




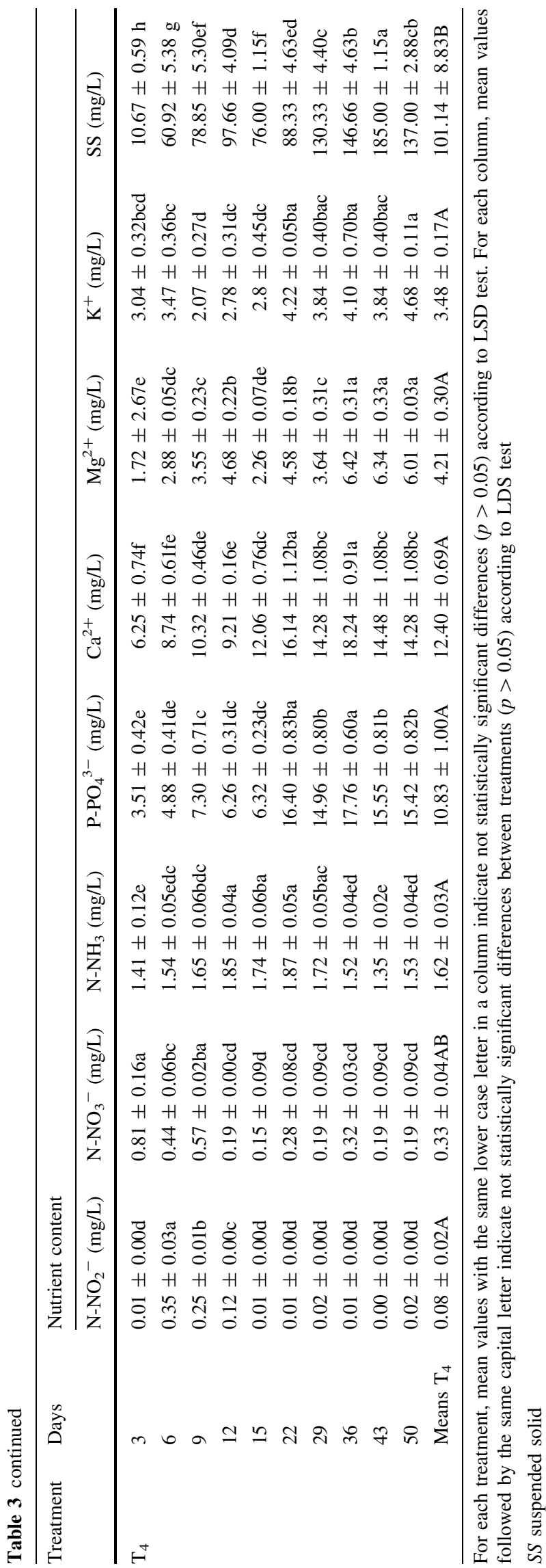

Overall, $T_{4}$ released the higher concentrations of nutrients being able to be used for fish production systems by its contribution for primary production.

\section{Classification of treatments according to their nutrient profile}

Figure 2 depicts the results of the PCA. All the variables can be classified according to the main components which explained $66.13 \%$ of the information $(51.61 \%$ for $\mathrm{F} 1$ and $14.52 \%$ for F2). The most correlated variables to $F 1$ were: conductivity, orthophosphate, suspended solid, total dissolved solids (TDS), salinity, magnesium, and nitrate (Table 4). Among these variables, those who contribute most to F1 were two different groups: for the first group conductivity, orthophosphate, suspended solid, salinity, and magnesium which are highly correlated between each other and negatively to F1, since they define eigenvectors same direction, and for the second group composed only by the nitrate which was positively correlated with F1 (Fig. 2a). On F2, the most correlated variables are temperature, $\mathrm{pH}$, and oxygen. However, some variables (potassium and ammonium) are near to centre of the factorial design, and their correlation is not certainly very strong. These variables are probably better explained by others minor components. Taking into account all the information provided by F1 and F2 (Table 4), the physicochemical parameters belonging to the axis F1, only orthophosphate was high and was at the origin of the mineralization, explaining the increase in conductivity, suspended solids, TDS, and salinity. The biochemical activity of degradation of the organic matter by microorganisms depends on the physical and chemical conditions of the environment. A temperature rise could increase $\mathrm{P}^{-} \mathrm{PO}_{4}{ }^{3-}, \mathrm{Ca}^{2+}, \mathrm{Mg}^{2+}$, SS concentrations, and salinity. Likewise, a rise in the temperature and $\mathrm{pH}$ is followed by an increase of nitrate concentration. Indeed, the fluctuation of temperature, dissolved oxygen, and $\mathrm{pH}$ modulate mineralization rate because of their key role on the microbial activity on organic matter.

\section{Discussion}

\section{Diet and manure's nutrient content}

The efficient uses of organic fertilizers necessitate a good knowledge of their nutrient contents. Nutrients released from organic manure constitute the key of the primary production. However, their excessive concentrations can negatively impact the aquatic environment (e.g., eutrophication). Therefore, it is essential to quantify their concentration in the aquatic environments to avoid such negative 


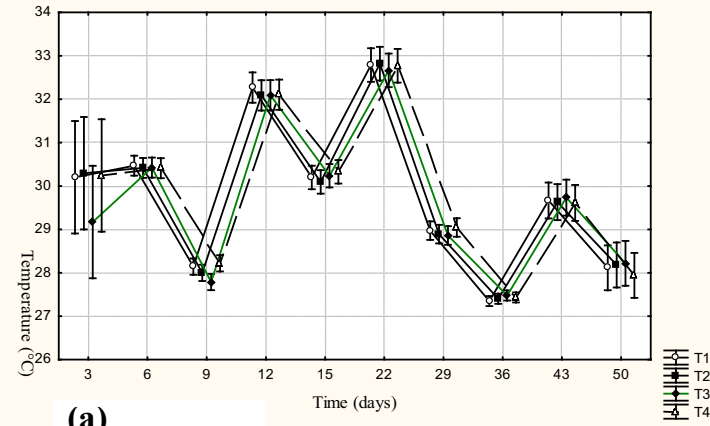

(a)

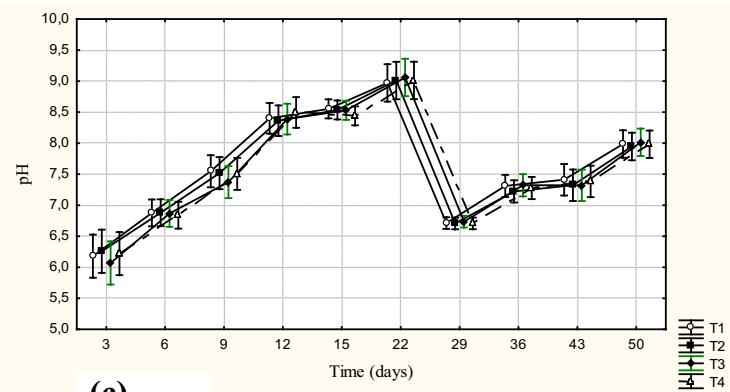

(c)

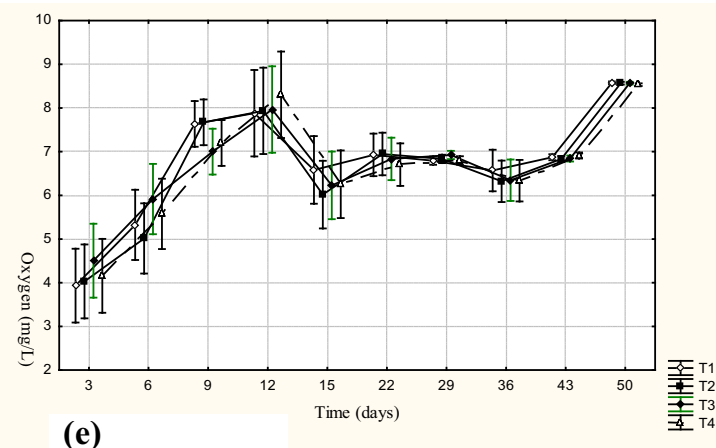

(e)

Fig. 1 Physico-chemical parameter of the various treatments according to time a temperature; $\mathbf{b}$ conductivity; $\mathbf{c} \mathrm{pH} ; \mathbf{d}$ total dissolved solid (TDS); e oxygen; and f salinity. Treatments' description: $T_{1}$

impacts or mitigate them. Our results showed that the nutrient content from the different types of rabbit manure varied qualitatively and quantitatively according to the tested diet. This result could be explained by the diet composition (nitrogen levels, phosphorus, potassium, calcium, magnesium, etc.). This is in line with MartinezBallestra et al. (2008) who noted that the concentrations of these nutrients in animal waste strongly depend on the composition of food rations. Rations are influenced by factors such as the species, type of digestion, chemical composition, and presence of secondary compounds (Mackie 2002; Michelland et al. 2012). The concentrations of $1.26 \mathrm{mg} / \mathrm{L}$ of phosphorus for $\mathrm{T}_{4}$ and $16.34 \mathrm{mg} / \mathrm{L}$ of nitrogen for $\mathrm{T}_{2}$ were higher than those found by Vodounnou et al. (2016), which were $0.011 \mathrm{mg} / \mathrm{L}$ for phosphorus

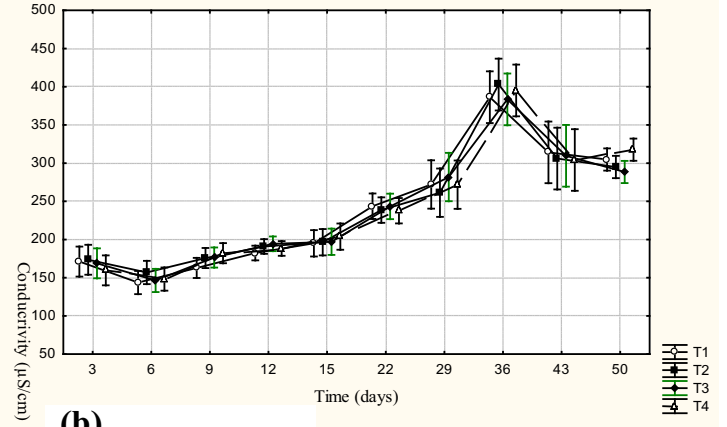

(b)
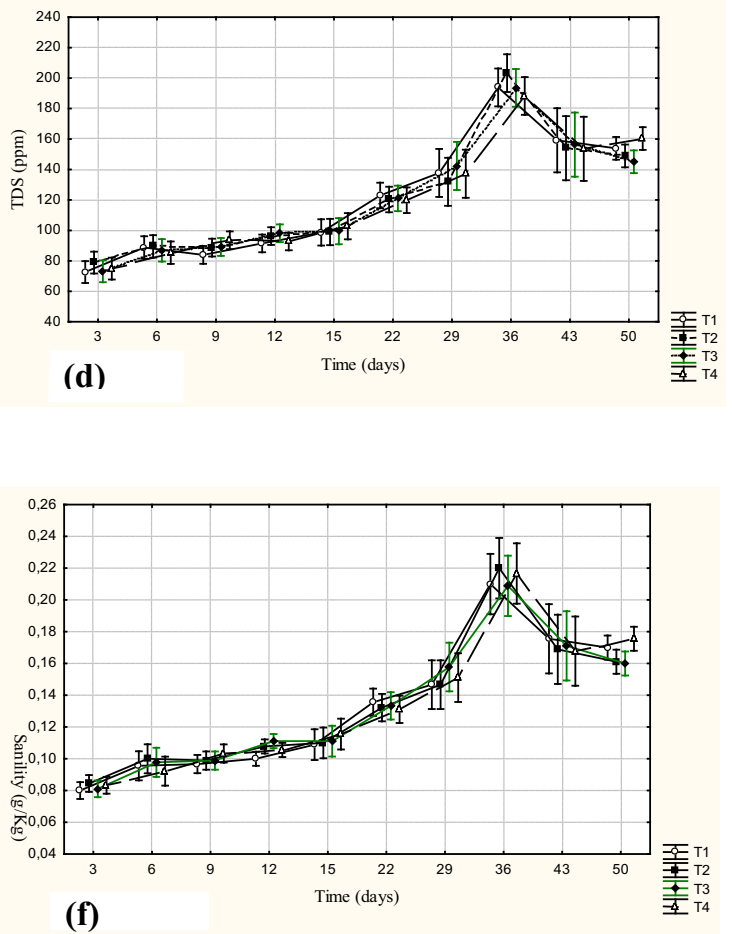

manufactured diet, $T_{2}$ improved diet with Ipomea aquatica, $T_{3}$ improved diet with Elaeis guineensis, and $T_{4}$ improved diet with Panicum maximum

and $0.025 \mathrm{mg} / \mathrm{L}$ for nitrogen in rabbit manures. This difference could be explained by the type of tested diets and rabbit species used in one hand, and the conservation process of these rabbit manures in the other hand. However, these results are lower than those obtained by Bokossa et al. (2014a) on manure from pigs fed with Azolla and rice bran. This difference is due to the composition of diets and digestibility of rations applied to monogastric animals. Indeed, rabbits have a complex digestive physiology compared to other herbivores and omnivores.

The value of the N:P ratio indicates which one between $\mathrm{N}$ and $\mathrm{P}$ is the limiting factor. According to rough nutrient balance estimation, the best ratio for sustainable aquaculture production was that obtained with treatment $\mathrm{T}_{2}$ $(\mathrm{N}: \mathrm{P}=15: 1$ and $\mathrm{N}: \mathrm{P}: \mathrm{K}=18: 1: 1)$, but $\mathrm{N}: \mathrm{P}$ ratio was 


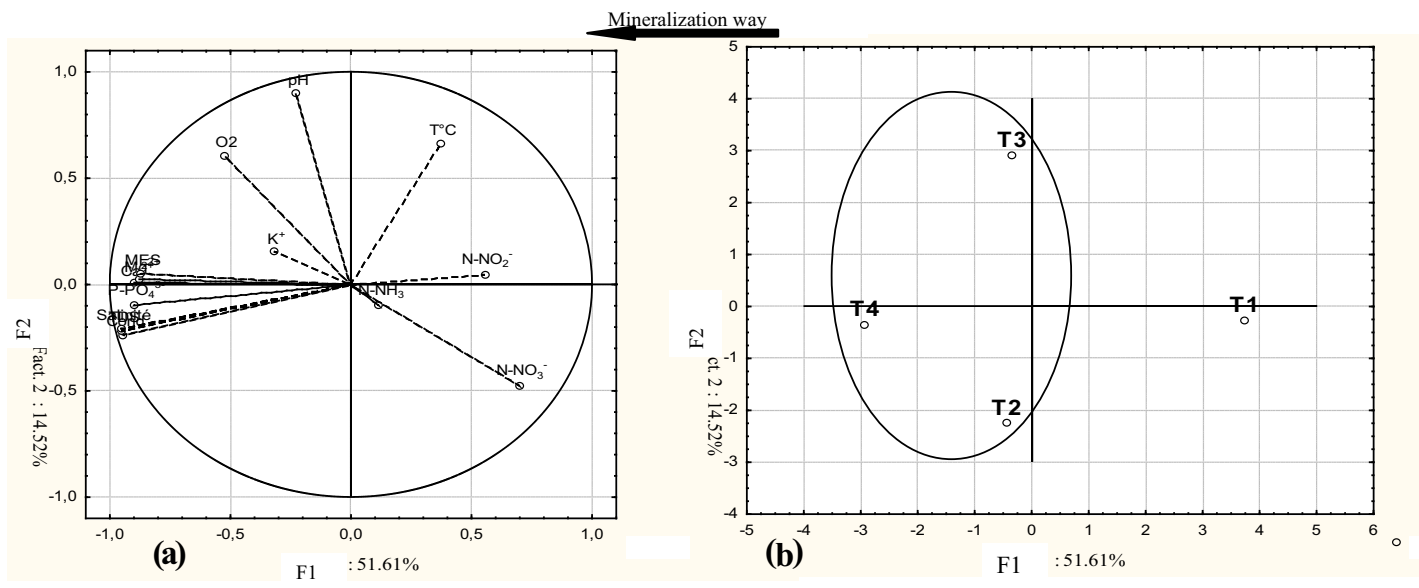

Fig. 2 Principal component analyses of treatments and their effect on water quality. a Correlation between chemical parameters; $\mathbf{b}$ classification of treatments

Table 4 Correlation coefficients between variables and axis principal

\begin{tabular}{|c|c|c|}
\hline & Factorial axe 1 & Factorial axe 2 \\
\hline $\mathrm{N}-\mathrm{NO}_{2}{ }^{-}$ & 0.55 & 0.04 \\
\hline $\mathrm{N}-\mathrm{NO}_{3}{ }^{-}$ & 0.69 & -0.47 \\
\hline $\mathrm{N}-\mathrm{NH}_{3}$ & 0.11 & -0.09 \\
\hline $\mathrm{P}-\mathrm{PO}_{4}^{3-}$ & -0.90 & -0.09 \\
\hline $\mathrm{Ca}^{2+}$ & -0.89 & 0.00 \\
\hline $\mathrm{Mg}^{2+}$ & -0.87 & 0.02 \\
\hline $\mathrm{K}^{+}$ & -0.31 & 0.15 \\
\hline SS & -0.87 & 0.04 \\
\hline $\mathrm{T}^{\circ} \mathrm{C}$ & 0.37 & 0.66 \\
\hline $\mathrm{O}_{2}$ & -0.52 & 0.60 \\
\hline $\mathrm{pH}$ & -0.22 & 0.89 \\
\hline Cond & -0.94 & -0.23 \\
\hline TDS & -0.94 & -0.21 \\
\hline Salinity & -0.95 & -0.20 \\
\hline
\end{tabular}

between 10:1 and 20:1 for all treatments (Borchardt 1996). This ratio from our study confirmed the enrichment of $\mathrm{T}_{4}$ treatment in phosphorus. These results are similar to those obtained by Güsewell and Verhoeven (2006) and Guckland et al. (2009), where N:P ratio was 16:1 during the decomposition of leaves and 11:1 in the soil, respectively.

Panicum maximum at 3 week age contains $32.3 \%$ calcium, $46.6 \%$ phosphorus, and $71 \%$ of magnesium (Oyenuga 1960). These high contents of magnesium and phosphorus in the form of orthophosphate contribute to their high growth, density, biomass, and net primary production (Rejmánková 2001; Cody et al. 2010). The high phosphorus content recorded in treatment $\mathrm{T}_{4}$ would play a crucial role in phytoplankton production in fish net.

\section{Effect of rabbit manure on nutrient dynamics and water quality}

The experiment took place during the dry season with temperature fluctuating between 28 and $30{ }^{\circ} \mathrm{C}$. It had played an important role in organic matter mineralization, but also induced a good solubility and diffusion of gases such as oxygen in water (Belghiti et al. 2013; Bokossa et al. 2014b). The speed of oxygen diffusion depends for a large part on the contact area between air and water. The quantitative importance of this process depends on the temperature, light, and richness in nutrients. After the water fertilization was achieved, 3 day latency time (enzymatic adaptation) was observed during which values of chemical parameters did not varied a lot. The $\mathrm{pH}$ remained around 6 in all the treatments. Microbial activity started thus after these 3 days and showed a fast variation of these parameters (Table 3); $\mathrm{pH}$ and $\mathrm{P}_{-} \mathrm{PO}_{4}{ }^{3-}$ increased, whereas nitrogen forms showed great fluctuation (nitrification process) providing a favourable environment for phytoplankton production (Fig. 1e), and consequently that of zooplankton when phytoplankton biomass is not so high to cause growth inhibition (Liady et al. 2015 and references there in). Indeed, the extent of $\mathrm{pH}$ preferences for fish is usually 5-7 to 7-9 (Peterson et al. 1989). Our findings were like those obtained by Bokossa et al. (2014a). The high content of suspended solids can be correlated with all inorganic and organic substances contained in a liquid, the total dissolved substances in water and salinity in the mineral environment released from rabbit manures during mineralization in $\mathrm{T}_{4}$ and $\mathrm{T}_{2}$. This corroborates the results of Guibaud et al. (2013) on the effect of mineralization in fresh water with waste and with various anthropogenic activities in Morocco (Nechad et al. 2014). The organic fertilizer decomposition is assured by heterotrophic 
microorganisms which release various minerals while consuming oxygen (Mérigout 2006). The different values of nitrite recommended in fish farming ponds range from 0.5 to $2 \mathrm{mg} / \mathrm{L}$ (Dwamd 1994). This tendency which was found in $T_{1}, T_{2}$, and $T_{3}$ around the 36th day of the experiment confirms the results obtained by Grunert et al. (2016) during the conversion of nitrogen in the growth of horticultural plants. This decline could be explained by the low phosphorus content in rabbit manures in our experiments. Phosphorus content was important in $\mathrm{T}_{4}$ and explains that the degradation of organic matter continues under its influence. In fact, phosphorus allows microorganism's longer life time than nitrogen (Durand et al. 1983). The orthophosphate content from $\mathrm{T}_{4}$ was higher than those obtained by Bokossa et al. (2014a), whose maximum value was $2.80 \mathrm{mg} / \mathrm{L}$. This difference could be explained by the type of organic fertilizer, animal species, and tested diet. The phosphorus richness in $\mathrm{T}_{4}$ can be a reliable source of mineralization for the development of aquaculture. The nutrient concentrations in the rabbit manure can be used to a good production of microalgae in aquaculture systems, namely, because of their role on microalgae's growth in freshwater (Martin et al. 1985). The high concentrations of $\mathrm{K}^{+}, \mathrm{Ca}^{2+}$, and $\mathrm{Mg}^{2+}$ in $\mathrm{T}_{4}, \mathrm{~T}_{3}$, and $\mathrm{T}_{2}$ proved the presence of released nutrients in water and justify the high conductivity obtained. Suspended solids induced degradation of aquatic ecosystems by reducing light penetration in water, damage the gills of fish, total or partial closure of habitats, and spawning leading depletion oxygen and create a hostile environment for the life of aquatic organisms (Massa 2000; Foster and Charlesworth 1996), but from our results, the low value of suspended solid in $T_{3}$ and $T_{4}$ treatments is a worthy asset for aquaculture production.

\section{Correlation between physicochemical variables and nutrient dynamics}

The use of PCA clarifies the relationships between variables and phenomenon behind these correlations (Fig. 2a). It is used in many water dynamic studies and facilitates aquatic ecosystem studies (Ladhar et al. 2014). PCA showed that the mineralization was related mainly to orthophosphate content and to some extent to ammonium, calcium from which increasing conductivity. These results are different from those obtained by Amadou et al. (2014) in physicochemical and bacteriological analyses of wastewater. The most important effect of the mineralization in our study was characterized by high levels of orthophosphate in $\mathrm{T}_{4}$ which is a major source of plant nutrients (Fig. 2b). Similar results were observed by Diallo et al. (2014), and highlight the inseparable link between orthophosphates and the growth of plants and even point out its essential role in eutrophication process. The increase in conductivity is correlated with increased nutrient levels (Belghiti et al. 2013; Rodier et al. 2012; Bokossa et al. 2014a). Indeed, $T_{2}$ and $T_{4}$ released nutrients such as nitrogen, phosphorus, potassium, and calcium, which are the cause of the increase in conductivity. We noticed a nitrogen loss during the mineralization process. It would be necessary to offer to agriculture and fish farmers a contribution on a regular way of use of rabbit manures to fill the gap.

\section{Conclusion}

Following the results obtained from the mineralization process of different rabbit manures in fresh water, we can conclude that it can serve as enrichment for fresh water in agro-piscicultural systems. Nutrients released from organic wastes (as rabbit manure) can provide a good yield in such systems at a lower cost compared to chemical fertilizers. This study of enrichment of water by rabbit manure resulting from different diets including classic diet $\left(\mathrm{T}_{1}\right)$, improved diet with I. aquatica $\left(\mathrm{T}_{2}\right)$, improved diet with $E$. Guineensis $\left(\mathrm{T}_{3}\right)$, and improved diet with $P$. Maximum $\left(\mathrm{T}_{4}\right)$ showed that the mineralization moved towards orthophosphates, calcium, and magnesium. Treatments $\mathrm{T}_{4}, \mathrm{~T}_{2}$, and $\mathrm{T}_{3}$ had good physicochemical characteristics offering favourable conditions for fish production by the means of algae production (phytoplankton), contrary to the treatment $T_{1}$. Moreover, $\mathrm{T}_{4}$ treatment because of its high phosphorus content offers more optimal conditions for the production of microalgae. Water quality in terms of minerals content varies according to the diets.

Acknowledgements We express our gratitude to the Ministry for the Higher Education and Scientific Research of Benin, which set up the project "support at $\mathrm{PhD}$ student" in which this study of research was made.

\section{Compliance with ethical standards}

Conflict of interest The authors declare that there is no conflict of interest.

Open Access This article is distributed under the terms of the Creative Commons Attribution 4.0 International License (http://crea tivecommons.org/licenses/by/4.0/), which permits unrestricted use, distribution, and reproduction in any medium, provided you give appropriate credit to the original author(s) and the source, provide a link to the Creative Commons license, and indicate if changes were made.

\section{References}

Agadjihouèdé H, Montchowui E, Chikou A, Lalèyè PA (2011) Libération comparée de sels dans l'eau par la minéralisation de l'azolla, la bouse de vache, la fiente de volaille et les sons de riz 
et de maïs utilisés en pisciculture. Int $\mathrm{J}$ Biol Chem Sci 5:1883-1897. doi:10.4314/ijbcs.v5i5.10

Akodogbo HH, Bonou CA, Adande R, Sossou DS, Fiogbé ED (2015) Optimization of zooplankton production from pig dung optimal dose: renewed medium. Agric Adv 4:15-21. doi:10.14196/aa. v4i2.1804

Amadou H, Laouali MS, Manzola A (2014) Analyses physicochimiques et bactériologiques des eaux de trois aquifères de la région de Tillabéry: application des méthodes d'analyses statistiques multi variées. Lar J 20:25-41

Belghiti ML, Chahlaoui A, Bengoumi D, Moustaine REL (2013) Etude de la qualité physico-chimique et bactériologique des eaux souterraines de la nappe plio-quaternaire dans la région de meknès (Maroc). Lar J 14:21-36

Bokossa HKJ, Saïdou A, Fiogbé ED, Kossou D (2014a) Decomposition rate of pig's manures and nutrient release pattern in wetland condition. Agric For Fish 3:271-278. doi:10.11648/j.aff. 20140304.19

Bokossa HKJ, Saïdou A, Sossoukpe E, Fiogbé DE, Kossou D (2014b) Decomposition and mineralization effect of various sources of Pig manure on water quality and nutrients availability for agroFish System in Benin. Agric Sci 5:1194-1206. doi:10.4236/as. 2014.512129

Borchardt MA (1996) Nutrients. In: Stevenson RJ, Bothwell ML, Lowe RL (eds) Algal ecology: freshwater benthic ecosystems. Ac Press, San Diego, pp 183-227

Cody RJ, Luecke C, Whalen SC, Evans MA (2010) Direct and indirect effects of fish on pelagic nitrogen and phosphorus availability in oligotrophic Arctic Alaskan lakes. NRC Sci 67(10):1635-1648. doi:10.1139/F10-085

Diallo AD, Ibnonamr K, N'diaye AD, Garmes H, Kankou M, Wane O (2014) L'intérêt des méthodes d'analyses statistiques dans la gestion du suivi de la qualité physicochimique de l'eau de la rive droite du fleuve Sénégal. Lar J 17:101-114

Durand M, Beaumatin P, Dumay C (1983) Estimation in vitro à l'aide du phosphore radioactif des besoins en phosphore des microorganismes du rumen. Reprod Nutr Dév 23:727-739

Dwamd (1994) Division of water ambient monitoring database, 18th edn p 325

FAO (2010) (Food and Agriculture Organization). Statistical databases. rome: fao [online]. http://www.fao.org. Accessed 09 Oct 2016

FAO (2012) (Food and Agriculture Organization). The State of world fisheries and aquaculture, 2000, p 230

Foster IDL, Charlesworth SS (1996) Hearvy metals in the hydrological cycle: trends and explanation. Hydr Processes 10(2): 227-261

Goulding K, Jarvis S, Whitmore A (2008) Optimizing nutrient management for farm systems. Philos Trans R Soc B 363:667-680. doi:10.1098/rstb.2007.2177

Grunert O, Reheul D, Labeke MCV, Perneel M, Sanabria EH, Siegfried EV, Boon N (2016) Growing media constituents determine the microbial nitrogen conversions in organic growing media for horticulture. Micro Biotechol 9:389-399. doi:10.1111/ 1751-7915.12354

Guckland A, Brauns M, Flessa H, Thomas FM, Leuschner C (2009) Acidity, nutrient stocks and organic matter content in soils of a temperate deciduous forest with different abundance of European beech (Fagus sylvatica L.). J Plant Nutr Soil Sci 172: $500-511$

Guibaud G, Charriau A, Bordas F, Rabiet M (2013) Evaluation, through the measurements of electric conductivity and mineral compound contents in waters and soils, of the impact of an old municipal landfill on a wetland (peat bog). Eur J Water Qual 44:13-38
Güsewell S, Verhoeven JTA (2006) Litter N: p ratios indicate whether $\mathrm{N}$ or P limits the decomposability of graminoid leaf litter. JTA Plant Soil 287:131. doi:10.1007/s11104-006-9050-2

Kaushik S (2014) L'apport de la pisciculture à l'alimentation de l'homme. Cah Agric 23:18-23. doi:10.1684/agr.2014.0679

Ladhar C, Tastard E, Casse N, Denis F, Ayadi H (2014) Strong and stable environmental structuring of the zooplankton communities in interconnected salt ponds, p15. Hydro. doi:10.1007/s10750014-1998-y

Lazard J (2014) La diversité des piscicultures mondiales illustrée par les cas de la Chine et du Nigeria. Cah Agric 23:24-33. doi:10. 1684/agr.2014.0680

Lemaire G, Franzluebbers A, Carvalho PCF, Dedieu B (2013) Integrated crop-livestock systems: strategies to achieve synergy between agricultural production and environmental quality. Agric Ecosyst Environ 190:4-8. doi:10.1016/j.agee.2013.08.009

Li SF (2002) Aquaculture research and its relation to development in China. In: Zhang LX, Liu J, Li SF, Yang NS, Gardiner PR (eds) Agricultural development and the opportunities for aquatic resources research in China. World Fish Center, Penang, p p58

Liady MND, Tangou TT, Fiogbe ED, Cauchie HM, Vasel JL (2015) About the interest of a zooplankton compartment in pond systems: methodology to study the growth of $D$. pulex. Wat Sci Technol 71:1436-1443

Mackie RI (2002) Mutualistic fermentative digestion in the gastrointestinal tract: diversity and evolution. Int Comp Biol 42:319-326

Martin C, Picard G, de la Noüe J (1985) World Epuration biologique du lisier de porc par production de biomasses d'algues unicellulaires. J Microbiol Biot 1:173. doi:10.1007/BF01742582

Martinez-Ballestra MC, Lopez-Perez L, Hernandez M, LopezBerenguer C, Fernandez-Garcia N, Carvajal M (2008) Agricultural practices for enhanced human health. Phyto Chem Rev 7:251-260. doi:10.1007/s11101-007-9071-3

Mascha J, Karin V, Andrea P, Frank MT (2010) Leaf litter decomposition in temperate deciduous forest stands with a decreasing fraction of beech (Fagus sylvatica). Ecol 164:1083-1094. doi:10.1007/s00442-010-1699-9

Massa F (2000) Sédiment, physico-chimie du comportement interstiel et développement larvaire de la truite commune (Salmo-trutta) : Etude en milieu naturel antropisée et en condition contôlée, Thèse de l'INA-P-G, p. 199

Mérigout $\mathrm{P}$ (2006) Etude du métabolisme de la plante en réponse à l'apport de différents fertilisants et adjuvants culturaux. Influence des phytohormones sur le métabolisme azoté. Sciences of the Universe [physics]. INAPG (AgroParisTech), 2006. HAL Id: pastel-00002273 https://pastel.archivesouvertes.fr/pastel00002273. Submitted on 22 Mar 2007

Michelland RJ, Combes S, Monteils V, Bayourthe C, Cauquil L, Enjalbert FJC, Kimse M, Troegeler-Meynadier AZA, Gidenne T, Fortun-Lamothe L (2012) Analyse comparée des écosystèmes digestifs du rumen de la vache et du caecum du lapin. INRA Prod Anim 25:395-406

Moura E Silva MS, Graciano TS, Losekann ME, Luiz AJ (2016) Assessment of benthic macroinvertebrates at Nile tilapia production using artificial substrate samplers. Braz J Biol 76(3):735-742. doi:10.1590/1519-6984.02815

Nechad I, Fadil K, Fadil F (2014) Qualité physicochimique des eaux des sources ain regrag et ain Sidi Bouali dans la région de Sefrou (moyen atlas, Maroc). Lar J 20:127-146

Oyenuga AV (1960) Effet of stage of growth and frequency of cutting on the yield and chemical composition of some Nigerian fodder grasses-Panicum maximum Jacq. With 10 text-figures printed in Great Britain. J Agric Sci 55:339. doi:10.1017/S00218596 00023212 
Peterson RH, Coombs K, Power J, Paim U (1989) Responses of several fish species to $\mathrm{pH}$ gradients. Rev Can de Zool 67:1566-1572. doi:10.1139/z89-222

Pucher J, Steinbronn S, Mayrhofer R, Schad I, El-Matbouli M, Focken U (2012) Improved sustainable aquaculture systems for small-scale farmers in Northern Vietnam. Environ Sci and Eng, pp 4-8. doi 10.1007/978-3-642-33377

Qiu S, Mc Comb AJ, Bell RW (2012) Leaf litter decomposition and nutrient dynamics in woodland and wetland conditions along a forest to wetland hill slope. Int Sch Res Netw ISRN Soil Sci 12:8 (id 346850)

Rejmánková E (2001) Effect of experimental phosphorus enrichment on oligotrophic tropical marshes in Belize, Central America. Plant Soil 236:33. doi:10.1023/A:1011953715153
Rodier JBL, Merlet N, Coll (2012) Analyse de l'eau. 9e édition, DUNOD, p 20225

Steinbronn S (2009) A case study: fish production in the integrated farming system of the Black Thai in Yen Chau district (Son La province) in mountainous North-Western Vietnam-current state and potential. Ph. Dissertation, University of Hohenheim, Stuttgart

Vodounnou DSJV, Kpogue DNS, Tossavi CE, Mensah GA (2016) Effect of animal waste and vegetable compost on production and growth of earthworm (Eisenia fetida) during vermiculture. IRWA 5:87-92. doi:10.1007/s40093-016-0119-5

Wilkins RJ (2008) Eco-efficient approaches to land management: a case for increased integration of crop and animal production systems. Philos Trans R Soc B Biol Sci 363:517-525. doi:10. 1098/rstb.2007.2167 